Arnfinn Bø-Rygg

\title{
Det utholdte nullpunkt
}

\section{Om postmodernismen og dens forutsetning $i$ modernismen}

Den postmoderne kunsten er fremfor alt karakterisert ved at den fritt disponerer over kunstmidlene. Det er ingen "Kanon der Verbote« (Adorno) lenger; tvertimot proklameres "la fine del proibizionismo « (Paolo Portoghesi). Med den frie forføyning over materiale og former (inkludert fortidens) er den historiske tendensen i det estetiske materiale opphørt. Den forståelse av verket som fri konstruksjon som dette innebærer - verket som »tekst« i poststrukturalistisk forstand - åpner for et mangfold av muligheter, der det ikke lenger er én bestemt materialestandard, ett estetisk formnivå.

\section{$I$}

Den frie forføyning over kunstmidlene og samtidigheten av forskjellige materialstandarder er ifølge Peter Bürgers grunnleggende studie over avantgardens teori allerede muliggjort med den historiske avantgarde. Jeg vil her hevde at Bürgers hovedteser om den historiske avantgarde på mange måter er eller impliserer en teori om postmodernismen. Jeg skal først kort skissere hovedpoenget i Bürgers bok for så å utvide dets gyldighetsområde.

Med »historisk avantgarde« mener Bürger dadaismen, den tidlige surrealismen, den russiske avantgarde etter oktoberrevolusjonen, men også til en viss grad den tyske ekspresjonismen, kubismen og den italienske futurismen - bevegelser særlig i maleri og litteratur som søkte å oppheve kunsten i livspraksis og organisere en ny livspraksis ut fra kunsten. Avantgarde-bevegelsenes angrep på selve kunstens status i samfunnet (institusjonen kunst) var etter Bürgers mening muliggjort i og med estetisismen, der den borgerlige kunstens karakter (autonomistatusen) var blitt klargjort. Bürgers utviklingslogiske poeng er at avantgarden når selvkritikkens stadium. Det innebærer at den forholder seg kritisk, ikke bare til den kunstneriske tradisjon, eller til samfunnet, men til sin egen utvikling, til selve kunstens status (autonomien) i samfunnet. Avantgardebevegelsene søkte å oppheve 
kunsten i handling (dadaismen), i uttrykk (ekspresjonismen) og ved å revolusjonere hverdagen (surrealismen). Det er ikke tale om å utslette kunsten, men om en ophevelse i Hegels forstand: »Kunsten skal overføres i livspraksis der den i forvandlet gestalt vil være oppbevart.«

På samme måte som kunsten med avantgarde-bevegelsene forholder seg til seg selv på en helt annen måte enn før, kommer også kunstens egne fremgangsmåter, kunstmidlene, inn i refleksjonen. Bürgers tese er at kunstmidlene, som kunsten alltid anvender, blir erkjent på en almen måte $i$ og med avantgarden, for først her kan helheten av de kunstneriske midler fritt forføyes over. Skapelsesprosessen er blitt et rasjonelt valg mellom forskjellige fremgangsmåter, alt etter hvilken virkning man ønsker. Dette forutsetter den høye grad av rasjonalitet $i$ den kunstneriske produksjon som kunsten i modernismen hadde nådd, men altså først og fremst at kunstmidlene er blitt fritt disponerbare, at de »hverken er omrammet av en epokes stil eller en kanon av fremgangsmåter som bare til en viss grad kunne overskrides."

Etter den historiske avantgarde, det Bürger kaller den postavantgardistiske kunsten, vil det derfor ikke være noen klar utviklingslogikk i kunsten. Flere materialstandarder vil kunne befinne seg ved siden af hverandre (f.eks. abstraksjon og realisme), uten at det er mulig å trekke frem én som den mest avanserte. Bürger mener derfor, mot Adorno (jfr. nedenunder), at én bestemt kunstnerisk bevegelse senest siden de historiske avantgardebevegelsene ikke lenger kan legitimere et krav om å være den mest avanserte.

Bürger kan kalle avantgarde-bevegelsene historiske fordi deres angrep på institusjonen kunst mislyktes; kunsten ble ikke opphevet $\mathbf{i}$ livspraksis. Tvertimot ble selv de mest ekstreme forsøk på å oppheve kunsten, tatt inn i institusjonen og gjort til autonome verker. Men fordi tilbakeføringen til livspraksis mislyktes, kommer senere forsøk på det samme, neo-avantgarden i 50- og 60-årene, i en annen situasjon: Neo-avantgarden institusjonaliserer avantgarden som kunst $\mathrm{og}$ negerer derfor det egentlig avantgardistiske.

Man kan ha mange innvendinger mot det idealtypiske i Bürgers fremstilling, og særlig mot hans vurdering av neo-avantgarden. Det skal ikke diskuteres her. Fruktbart hos Bürger er først og fremst påpekningen av kunstmidlenes frie forfoybarhet og samtidigheten av forskjel- 
lige materialnivåer. Min tese er imidlertid at også der i den moderne kunsten, hvor vi ikke har med intensjonen om å oppheve verket å gjøre (autonomien), - nemlig innenfor det vi kan kalle den hermetiske eller høye modernismen - får vi å gjøre med et opphør av materialedialektikken og dermed en fri disponering over kunstmidlene. Poenget er mer at den prosess som estetismen igangsatte, og som hadde sitt grunnlag i det estetisk moderne (fra ca. 1850), gjorde at forminnhold-dialektikken $\mathrm{i}$ kunsten stadig forskjøv seg til fordel for formen. Kunstmidlene erkjennes som kunstmidler jo mer "innholdet« svinner, som Bürger sier. Vi kan da si at den frie forføyning er endepunktet $\mathrm{i}$ denne utvikling, der materialet frilegges uten å ha noen bestemt tendens. Når kunstmidlene blir disponert fritt, endres forholdet til historien; kunstneren forholder seg i prinsippet ahistorisk. Dette er et hovedtrekk ved den postmoderne estetiske erfaring.

Den hermetiske modernismen i maleriet - den tiltagende abstraksjon, planhet henimot total reduksjon (Rotkho, Neroman) - kan sees i perspektivet fra nedbyggingen av materialets historiske tendens. Men særlig klart blir dette hvis vi tar musikken som eksempel. Dette skulle være desto rimeligere å gjøre, siden Bürger jo henter materiale-begrepet fra Adorno, hvor det først og fremst står for det musikalske materiale. Noen direkte parallell til de historiske avantgarde-bevegelsene på musikkens område lar seg neppe finne. Saties »dadaistiske« stykker, Russolos larmmusikk eller Varèse tilsvarer disse retninger bare i en viss forstand og utgjør ikke sentrum i den musikalske avantgarde. Stravinskys "analytiske kubisme« $\mathrm{i}$ »Sacre du printemps « eller hans »surrealisme« $i$ »L'histoire du soldat « kommer nærmere, men innebærer ikke noe angrep på autonomistatusen.

Imidlertid er Stravinsky det beste eksempel på fri forføyning av tradisjonens former og materiale. Stravinsky bøyde aldri av fra modernismens krav om innovasjon, men han fant det samtidig ikke mulig å videreføre, immanent, en bestemt historisk tendens i materialet. Hans utvendighet til materialet - ironien, parodien, montasjen, maskeraden - har tydelige fellestrekk med den historiske avantgarde. I dette perspektiv er det klart at Adornos Stravinskykritikk i Philosophie der neuen Musik til syvende og sist er en kritikk av avantgardetrekkene i denne musikken.

Men vi kan også si at Schönberg selv - innbegrepet av hermetisk modernisme - brakte materiale-dialektikken til opphør når han i sine senere verker (i det amerikanske eksil) forholdt seg til historien. Han når her en ny frihet overfor materialet, det viser seg til og med at det lar seg disponere tonalt. Etter å ha trukket konsekvenser av og utkomponert aporiene i materialets tendens, trer Schönberg ut av ma- 
teriale-dialektikken og forholder seg bevisst ahistorisk.

Også Anton Webern, som ble utgangspunkt for etterkrigstidens musikalske avantgarde (Darmstadt-skolen), vinner en ny utvendighet til materialet ved å gjøre musikkens enkelte elementer disponerbare til en fortetting av fortidens musikalske erfaring i stykker av minimal varighet. Når serialistene senere videreutvikler rekkeprinsippet til å gjelde samtlige parameter $\mathrm{i}$ musikken, når de frem til et komplekst materiale som ikke peker i noen bestemt retning. Det var neppe tilfeldig at serialistene oppdaget og utnyttet elektrofoniens muligheter. Med elektrofoniens »hvite brus« er materialet drastisk brutt ned til et nullpunkt og helt overlatt komponisten.

\section{III}

Stravinskys utvendighet til materialet, den sene Schönbergs disponering av fortidens musikalske erfaring, serialistenes nedskrivning av materialet til et nullpunkt, utgjør - på forskjellig måte, fra forskjellig kant - betingelser for det som siden inngår som konstituerende trekk ved den postmoderne erfaring: befrielsen fra materialets historiske tendens, befrielsen fra tradisjonens tyngde. I den aktuelle postmoderne estetiske erfaring inngår så andre komponenter der kanskje den viktigste ble bestemt gjennom en annen type nedbryting, som for musikkens vedkommende mest drastisk kommer til uttrykk i John Cages inndragelse av hverdagens mest heterogene lyder (inkludert stillhet).

En av Gages viktigste inspirasjonskilder var dadaismen (Satie, Duchamp), som for lengst var utdødd i Europa da den gjenoppstod i USA på 50-tallet. Cage (og hans kollega i malerkunsten: Rauschenberg) deler dadismens og surrealismens hovedintensjon: å oppheve skillet mellom kunst og liv. I hans "we must wake up to the very life we are living « og Leslie Fiedlers »cross the border, close the gap « har vi å gjøre med denne mer affirmative modernismetradisjon, som i 60og 70-årene førte med seg en nedbryting av grensene mellom kunstartene i performance og multi-media produksjon. Denne modernismen eller bedre: avantgardismen, står i motsetning til den klassiske, negative modernismen, ofte preget av formalisme, strenghet, internasjonal stil. Det var denne affirmative modernisme man i begynnelsen av 60årene begynte å kalle "postmodernisme« (jfr. nedenunder).

Men vi kan, interessant nok, også finne en annen inspirasjonskilde for Cages prosjekt. Cage, som hadde to års intense studier med 
Schönberg fra 1934-36 - et studium som opplagt er undervurdert i sekundær-litteraturen - sier i et brev at han valgte Schönberg fremfor Stravinsky som lærer på grunn av tolvtoneteknikken, »eller som jeg oppfatter det: på grunn av likeverdigheten mellom de tolv tonene uten at noen er dominerende.«

Det meste av det Cage gjør, kan oppfattes som en videreføring av dette prinsipp ut $i$ det ekstreme, inntil det omfatter all lyd. Hans tilfeldighetsoperasjoner - enten de kommer i stand gjennom terningkast, ujevnheter i papiret eller ved hjelp av tilfeldighetsspill fra den antikke kinesiske orakelboken »I Ching « - bevirker en likhet og likeverdighet mellom lydverdiene som ifølge ham selv er en siste konsekvens av rekkeprinsippet. Prinsippet overføres på komponist, interpret og publikum. Når komponisten ikke lenger kan forutse det som kommer, brytes tanken om hans forestillingskraft ned. Interpretens oppgave blir å løse ut materiale, utløse prosesser (f.eks. flere av „Variations«). Med stumproduksjonen 4'33" (1952) er publikums rolle totalt forandret. Dette ekstremfenomen kan både sees som den endelige realisering av det intensjonsløse verk, som en kommentar til tradisjonen, som opphevelsen av kunst i liv, og som publikums egen musikalske praksis (jfr. Rauschenbergs hvite lerret fra omtrent samme tid).

Cages utvikling fra slutten av 60-årene, med verker som »HPSCHD« og den første av »Cheap Imitations«, virker umiddelbart som et brudd. For her forekommer bruk av materiale fra andre komponister og en tilbakevending til tradisjonell notasjon og full utkomponering av et nummer. Det prinsipp som han tidligere forkastet fordi det per definisjon umuliggjorde å ta inn det forsømte og oversette, nemlig intensjonen - dvs. valg, smak, vurdering - gjeninnføres. Men dette skjer hos Gage med selvreferansens logikk, for intensjonen var det eneste som til nå var utelukket. Slik er ringen sluttet, men poenget hos Cage er at heller ikke dette gjeninnførte moment får preferanse eller blir tillagt verdi. Det er tale om valg og smak som én blant mange fremgangsmåter. I Cages siste periode taes det kjente i musikken, det som tidligere ble ansett som uttømt, inn igjen som mulig materiale og mulige fremgangsmåter. Men det er selv tømt for verdi og brakt ned på samme nullpunkt som det Cage ellers har samlet på sin vei. Slik er Cage det autentiske uttrykk for den postmoderne situasjon, slik den ytrer seg i den frie disponering over et hvilket som helst materiale, inkludert fortidens.

Men det ligger en tvetydighet her som lett kan slå over i en ny absoluttering. Når dialektikken mellom det skjønne og det heslige helt utslettes, betyr ikke det at det estetiske forlates. "Nivelleringen 
oppover« (Susan Sontag) er úomgjengelig knyttet til en estetisering av sansningen, der lydene eller gjenstanden løsrives fra den sammenheng de står i og betraktes i seg selv. Snarere estetiseres alt, noe heller ikke Rauschenberg er fri for $i$ utsagn som at »Det er ingenting i veien for ikke å betrakte verden som et gigantisk maleri«. Absolutteringen av det estetiske kommer til utrykk $i$ utsagn som »all is pretty « (Andy Warhol) og "ugly is beautiful« (Robert Venturi). Cage vil nok til siste slutt holde fast ved en ikke-estetisk erfaring, som dermed får et mystisk preg (amerikansk transcendentalisme, zen-buddhistisk visdom). En avstand så liten men så skarp som en knivsodd skiller Cages paradigme om å »la lydene være seg selv« fra Warhols og Venturis utsagn.

\section{IV}

Jeg anser det nå som et særdeles viktig poeng for en forståelse av hva postmodernismen innebærer, at det er neo-avantgardens nedbryting av materialet utenifra og utvidelsen av det estetiske gjenstandsområde til å omfatte all slags akustisk avfall og hverdagens mest trivielle objekter (pop-art), som muliggjør en bevegelse tilbake, der nå også det tradisjonelle, det harmonisk skjønne, det ornamentelle, alt det som siden Baudelaire og Manet, Schönberg og Adolf Loos var suspekt, kan gjeninnfores. Tilbakevendingen til det skjønne og kjente - ornament, harmoni, velklang, figurasjon, representasjon; reauratiseringen i alle kunstarter som vi ser fra midten av 70-årene - er korrelatet til den nedbryting som tidligere hadde skjedd.

Dette betyr ikke å utelukke at 70-årenes reauratisering kan settes i forbindelse med den almene politiske og kulturelle "Tendenzwende«, slik f.eks. Habermas gjør. Men dette i seg selv vil aldri være noen god forklaring, likeså lite som f.eks. 50-årenes abstrakte kunst kan forklares direkte ut fra 50 -årenes politiske klima, slik man undertiden ser. Tesen om det nedbrutte materiale og utvidelsen av det estetisk mulige kan imidlertid bidra til å forklare hvorfor tilbakegrepet var mulig.

Til grunn for den postmoderne erfaring i kunsten ligger både en bevegelse utover (eksplosjon), mot omgivelsene, der omverdenens lyder eller tilfeldige objekter utgjør "verket«, og en bevegelse innover og bakover (implosjon), der tradisjonens former og stiltrekk er blitt disponerbare på en hittil ukjent måte. Enkelte kunstnere kan tillate seg å gjøre svært ulike ting, benytte fremgangsmåter som i modernis- 
men ville vært ansett som innbyrdes motstridende. F.eks. kan komponisten Dieter Schnebel skrive såkalte »tradisjonsstykke«, der han søker å opparbeide musikkens »tapte tid«, samtidig med at han fortsetter eksperimenteringen med å utvide lydbegrepet. Maleren Julian Schnabel kan si: »Jeg gjør én ting og siden noe helt annet; begge er sanne.« Portoghesi sammenligner arkitekten med et »insekt som bærer pollen fra en blomst til en annen".

Hvis vi nå vender oss mot begrepet 'postmodernisme', så ser vi at begge de to tendensene i kunsten, de subversive i 50- og 60-årenes neo-avantgarde og de på mange måter restaurative tendenser i 70årenes kunst, at begge disse omskrives med dette begrep. Jeg skulle $\mathrm{i}$ det foregående ha godtgjort at denne begrepsbruk er mulig. Det er faktisk ikke slik som mange synes å tro, at postmodernisme-begrepet ble dannet innenfor arkitekturen. Da Charles Jencks tok fatt i det i 1975 for å karakterisere nye tendenser i arkitekturen, hadde det allerede vært i bruk i ca. 15 år i amerikansk litterær debatt. Begrepet var der knyttet til en følelse av at modernismen gikk mot slutten, eventuelt allerede var ført til ende. Dette hang sammen med at det var blitt problematisk å opprettholde et enhetlig begrep 'modernisme'. Uttrykket brukes for å angi et brudd med modernismen, både av dem som beklaget det som et forfall (Harry Levin, Irving Howe) og dem som så det som frembruddet av en ny estetikk (Leslie Fiedler, Ihab Hassan). Det tilhengerne fremhevet, var de nye tendensenes reaksjon mot modernismens formalisme, dens strenghet og purisme, elitepreget og kravet om universalitet. Mot dette utmerket den postmoderne litteraturen seg ved å være »uren«, spille med forskjellige genrer, ved å oppta i seg elementer fra pop-kulturen, ved å tillate tilfeldighet eller stillhet, eller ved å ytre seg som happening og anti-kunst.

Etterhvert brukes betegnelsen "postmodernisme« på amerikansk grunn om kunst fra pop art til performance, samt om eksperimentering innenfor ballett, musikk og teater. Betegnelsen dekker altså det som ellers ofte kalles neo-avantgarden. For, mente man, på samme måte som Cage i musikken brøt med den strenge serialismen, var pop art og senere retninger som concept art et oppgjør med den abstrakte ekspresjonismen, og Living Theatre fremstod som et alternativ til det absurde teater.

Men betegnelsen overføres så fra ca. midten av 70-årene på historismen og eklektisismen $i$ arkitekturen og brukes fra ca. 1980 også om lignende tendenser i maleriet og musikken. Da så Habermas i sitt nå så berømte foredrag om det moderne prosjekt koblet dette postmodernisme-begrepet til det franske begrep om »la condition postmoderne«, samtidig som han lot modernisme-begrepet suges opp av 
(opplysnings)begrepet om det moderne - da var det for alvor duket for at begrepene "postmodernisme" og "postmoderne" kunne bli ideologiske stridsord.

Men ved å koble modernismen bruddløst til det moderne prosjekt, feies ikke bare tvetydigheten, motsigelsene og aporiene i modernismen bort, men også de motsetningsforhold kunstens estetiske rasjonalitet har til rasjonaliseringsprosessen og moderniseringen utviskes, motsetningsforhold som Adorno i høyeste grad hadde blikk for. Udialektisk avfeies den historiske avantgarde som en modernisme som har løpt løpsk. Derfor vil Habermas allerede i utgangspunktet ikke kunne se den radikale postmodernismen. Habermas' syn på modernismen som en integral del av den irreversible moderniseringsprosessen, gjør at han ensidig betoner kunstens rasjonalisering. Dermed kan han ikke trekke konsekvensene av at det med den frie forføyning over kunstmidlene og opphøret av materialets historiske tendens, blir svært problematisk å hevde at kunsten følger den fremadskridende rasjonalisering. Habermas' hårdnakkede opplysningsrasjonalisme viser seg ikke minst ved at beskrivelsen av det han ser som en alternativ estetisk erfaring, utelukkende gjøres i rasjonelle, kognitive og normative termer. Opplysningsrasjonalismen gjør også at han i sin ellers slående tidsdiagnose unyansert avfeier all fornuftkritikk som antimoderne og i siste instans konservativ. (Det er i dette perspektiv Habermas' siste oppgjør med Adorno må sees.)

Mot Habermas vil franske poststrukturalister og amerikanske dekonstruksjonister hevde at de restaurative tendensene intet har med postmodernismen å gjøre. Lyotard protesterer mot at eklektisismen i arkitekturen, tradisjonalismen i musikken, subjektivismen i maleriet og litteraturen overhodet får betegnelsen "postmodernisme«. En ekte postmodernisme vil for ham til og med bryte med enhver form for virkelighets-representering. Om maleriet sier han, at det dreier seg om "gjennom synlig fremstilling å henspille på noe ikke-fremstillbart« (en formulering som ikke ligger langt unna Adornos forestilling om en fremtidig »informell musikk «: »Dinge machen von denen wir nicht wissen was sie sind «). Når amerikanske kunstkritikere bruker uttrykket "postmodernisme" (jfr., f.eks. Rosalind Krauss, Craig Owens og diskusjonen i kunsttidsskriftet "October«), så siktes det til kunstnere som Rauschenberg, LeWitt, Richard Serra. Dette gjør de altså 
med full rett, ut fra den ene type postmodernisme, som innebærer en radikalisert modernisme.

Dette er en emfatisk bruk av begrepet, der også modernitetens ethos er bevart: "Il faut-être absolument postmoderne. « Men også den andre, restaurative eller nykonservative (i teorien) postmodernismen må taes inn i begrepet hvis vi bruker det i epokal forstand. For det nedbrutte materialet og den frie disponering åpner for, som vi så, begge deler: Både en flukt tilbake $\mathrm{i}$ tradisjonalisme og eklektisisme (postmodernisme som pastisj) og en selvreflektert postmodernisme eller kanskje bedre: postmodernisme som »dekonstruert« modernisme. Det er den førstnevnte postmodernisme som ikke er på høyde med den postmoderne situasjon. En flukt nettopp fra den postmoderne erfaring ser vi i den samtidskunsten som søker å skrive seg inn i en forgangen stil. Den frithet fra tidligere referansepunkt som situasjonen innebærer, er tung å bære. Den postmoderne situasjon gjør at kunsten må sette seg selv på spill på en hittil ukjent måte. Den emfatiske modernismen gjorde for såvidt også det, når den befridde seg fra forpliktelsen $i$ en almen stil, men materialenivået sikret for den et annet referansepunkt. Den frie forføyningen over materialet $i$ den postmoderne kunsten truer med uforbindtlighet og tilfeldighet. Det vanskelige $\mathrm{i}$ den postmoderne kunsten er at nå er det materialvalget som hver gang må vise seg tvingende. Det fins nok i den emfatiske postmodernisme et undertiden for sterkt innslag av "anything goes «, som vitner om holdningsløshet, estetisk nihilisme. Også på dette punkt har Cage formulert forskjellen: „Everything permitted, but only if zero is taken as the basis.«

\section{$V I$}

Den kanskje viktigste forskjell mellom modernismen og den radikale postmodernismen er forholdet til tiden og tradisjonen. Modernismen var, til tross for sin sporadiske kritikk av borgerlig fremskrittstro, båret opp av tanken om nødvendig utvikling og estetisk fremskritt. Adorno, modernismens fremste teoretiker, kunne tolke imperativet fra Rimbaud, om å være ubetinget moderne, som en forpliktelse overfor det fremskredne estetiske materiale. Det finnes en irreversibel standard for hva som er estetisk mulig.

Det felt som det nedbrutte materialet åpner, motsetter seg utviklingslogikk og lineære tendenser i kunsten. Men det betyr ikke at den postmoderne kunsten ikke endrer seg eller at det ikke er noe nytt $i$ 
den. Men endringen er ikke ordnet i sekvenser, og det gjør både periodisering og det å forestille seg historie som et monolittisk forløp, problematisk. Leonard $B$. Meyer har kalt denne situasjonen "a fluctuating steady-state«: Vi lever i en kultur som syder av aktivitet og forandring, men likefullt er statisk.

„Tidsånden« er det blitt like vanskelig å tro på som ikke å tro på $\mathrm{i}$ denne situasjon. For på den ene side kan vi si at dette forhold tilsvarer den postmoderne situasjon: det konstante nærvær av fortidens og samtidens kunstneriske uttrykk som står side om side og erstatter historisk forløp med simultanitet. Men på den annen side er forestillingen om en tidsånd knyttet til prinsippet om at alt ikke er mulig til alle tider (Wollflin), og det er dette prinsippet som synes å ha blitt satt ut av kraft: Kunsten behøver hverken å uttrykke sin spesifikke tid eller foregripe det kommende. Det eksisterer ikke lenger, som Mario Permiola sier, »et uløselig bånd mellom artistisk form og den sosialhistoriske tid som denne form eksisterer i.« Med et uttrykk som er karakteristisk for det gode spekulative i den latinske motfornuft, kaller Perniola denne vår nye tidserfaring for »den fullendte tid «: "Tiden eksisterer ikke mer, ikke fordi det ikke skjer noe nytt lenger, eller fordi alt allerede har skjedd, eller fordi alt nå kan forutsies. Tiden eksisterer ikke mer, fordi intet lenger kan ha del i et eksklusivt krav på, eller forhold til, tiden. Tiden må sees som fullendt - avsluttet, ferdig - fordi den nå hverken har en bestemt Kunstwollen eller en uadskillelig formal identitet.«

Den emfatiske postmodernismens forhold til tradisjonen innebærer noe nytt i forhold til alternativet historisme-modernisme. Det er ikke tale om, som i den dårlige postmodernismen, å skrive seg inn i en forgangen stil, ta på ny eller gammel stilmaske (jfr. George Rochbergs historisme i musikken, Carlo Maria Marianis neo-akademisme i maleriet, Krier-brødrenes antikvariske historisme i arkitekturen). Men heller ikke videreføres tradisjonen gjennom indre negasjon slik som i den hermetiske modernismen (Schönberg, det abstrakte maleriet, Mies van der Rohe i arkitekturen). Fortidens estetiske erfaring spaltes opp for så å settes sammen til nye konfigurasjoner (jfr. en komponist som Mauricio Kagel), eller tradisjonens erfaringer sett $i$ spill og inngår $\mathrm{i}$ konstellasjoner med vår egen, alt mens kunstens egen illusjonskarakter er selvforståelsens ramme (jfr. forfatteren Italo Calvino, komponisten Luciano Berio). James Stirlings museumsbygg i Stuttgart - et opus mixtum - har også denne karakter. I motsetning til det meste av postmodernismen $\mathrm{i}$ arkitekturen har det først dekonstruert fortiden for så å konstruere den på nytt. Det konsekvent fastholdte organiseringsprinsippet (modernismens erfaring) får en særegen letthet gjen- 
nom de talløse henspillinger på arkitekturhistorien. I billedkunsten er Robert Rauschenberg, som i likhet med sin venn Cage står på terskelen til postmodernismen, et tidlig eksempel på den overgang fra verk til »tekst" som postmoderniteten innebærer (jfr. verk som »Obelisk«, »Rebus«, »Allegori«). Leo Steinberg identifiserte i begynnelsen av 70-årene hans fremgangsmåte som et skifte fra natur til kultur. Det innebærer en radikalisering av det forhold som Foucault gjør oppmerksom på når det gjelder modernismens begynnelse (Manet), at først muséet gjør det mulig for maleriet å forholde seg til kategorien »maleri«.

Den emfatisk postmoderne kunsten er hverken realistisk, abstrakt eller symbolsk. Den åpner for allegorisk tydning. Men det vanskelige å gripe for oss som er innforstått med modernismen, er at den forlanger en allegorisk tydning uten melankoli. Den postmoderne kunsten er en lett kunst, avlastet både fra tradisjonens tyngde og fra kravet om a gripe utopien (også den negative). Men det utgår både "plaisir« og »jouissance fra den.

\section{Litteratur}

Peter Bürger: Theorie der Avantgarde, Frankfurt a.M. 1974.

Arnfinn Bø-Rygg: Modernisme, antimodemisme, postmodernisme. Kritiske streiftog $i$ samtidens kunst og kunstteori (Arbeidspapirer, Rogaland Distriktshøgskole 1983).

John Cage: Silence, London 1971.

Jürgen Habermas: „Die Moderne - ein unvollendetes Projekt«, i: Kleine Politische Schriften I-IV, Frankfurt a.M. 1981 .

Leonard B. Meyer: Music, the Arts and Ideas. Chicago/London 1967.

„October« fra ca. 1979 (MIT Press)

Mario Perniola: »Den fuldendte tid«, oversatt til dansk i: Slagmark, nr. 2/84. 